\title{
Effects of human pharmaceuticals on cytotoxicity, EROD activity and ROS production
}

\section{in fish hepatocytes.}

Laville N. ${ }^{\mathrm{a}, \mathrm{b}}$, Aït-Aïssa S. ${ }^{\mathrm{a}}$, , Gomez, E. $^{\mathrm{b}}$ and Casellas C. ${ }^{\mathrm{b}}$, Porcher J.M. ${ }^{\mathrm{a}}$

${ }^{a}$ Unité d'évaluation du risque écotoxicologique, INERIS, BP2, F60550, Verneuil-en-Halatte,

France

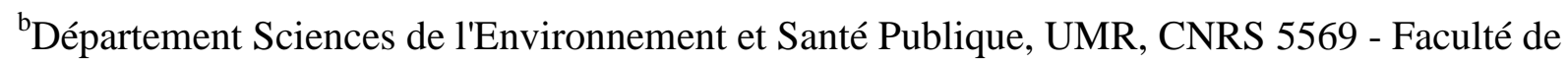
Pharmacie Avenue Charles Flahault, BP 14 491, F34093 Montpellier, Cedex 5 France

Corresponding author:

Nathalie LAVILLE

INERIS - BP n²

Parc Technologique ALATA

DRC / Ecotoxicology group

60550 Verneuil-en-halatte

France

$\underline{\text { Nathalie.laville-etudiant@ineris.fr }}$

Tel. (33) 344556790

Fax. (33) 344556767 
Keywords: Pharmaceuticals; PLHC-1; Primary Rainbow Trout Hepatocytes; Cytotoxicity; EROD; Oxidative Stress. 


\section{Abstract}

Pharmaceuticals are found in the aquatic environment but their potential effects on non-target species like fish remain unknown. This in vitro study is a first approach in the toxicity assessment of human drugs on fish. Nine pharmaceuticals were tested on two fish hepatocyte models: primary cultures of rainbow trout hepatocytes (PRTH) and on PLHC-1 fish cell line. Cell viability, interaction with cytochrome P450 1A (CYP1A) enzyme and oxidative stress were assessed by using 3-(4,5-dimethylthiazol-2-yl)-2,5-diphenyltetrasodium bromide tetrazolium (MTT), 7-ethoxyresorufin-o-deethylase (EROD) and dichlorofluorescein (DCFHDA) assays respectively. The tested drugs were clofibrate (CF), fenofibrate (FF), carbamazepine (CBZ), fluoxetine (FX), diclofenac (DiCF), propranolol (POH), sulfamethoxazole (SFX), amoxicillin (AMX) and gadolinium chloride $\left(\mathrm{GdCl}_{3}\right)$. All substances were cytotoxic, except AMX at concentration up to $500 \mu \mathrm{M}$. The calculated MTT $\mathrm{EC}_{50}$ values ranged from $2 \mu \mathrm{M}(\mathrm{CF})$ to $651 \mu \mathrm{M}(\mathrm{CBZ})$ in PLHC-1, and from $53 \mu \mathrm{M}$ (FF) to $962 \mu \mathrm{M}\left(\mathrm{GdCl}_{3}\right)$ in PRTH. CF, FF, and FX were the most cytotoxic drugs and induced oxidative stress before being cytotoxic. In PLHC-1 cells none of the tested drugs induced the EROD activity whereas on PRTH, POH appeared as a weak EROD inducer. Moreover, in PRTH, SFX, DiCF, CBZ and to a lesser extend, FF and CF inhibited the basal EROD activity at clearly sublethal concentrations which may be of concern at the biological and at the chemical level in a multipollution context. Finally, even if effective concentrations remained much higher than the environmental ones described in the literature, further in vivo investigations under chronic exposures are required before concluding on the potential toxicity of human pharmaceuticals to fish. 


\section{Introduction}

Pharmaceuticals are biologically active compounds widely used in human and veterinary medicine, agriculture and aquaculture. Parent compounds and metabolites have been reported to occur in surface, drinking and ground water as they reach the environment not only via hospital and domestic sewage treatment plant's effluents but also through landfill leachates and manufacturing residues. There is some evidence that many of these substances of pharmaceutical origin are not degraded by sewage treatment plants (STP) and are also not biodegradable in the environment (Andreozzi et al., 2002; Daughton and Ternes, 1999; Ternes, 1998).

Such observations have led scientists to consider the risk on aquatic biota. But to date, although therapeutic action, pharmacodynamic properties and side effects of drugs are well defined in mammals, their effects on non target species (Halling-Sorensen et al., 1998), particularly, their potential toxic effects on fish cells remain unknown. In this line, it has been pointed out that, pharmacodynamic effects classified as secondary and considered irrelevant for the therapeutic activity in human, might potentially play a major role in non-mammalian organisms. Moreover, the human primary pharmacodynamic activities of drugs could induce effects totally different from the therapeutic ones in non-mammalian organisms (Seiler, 2002).

The aim of this study was to give a first overview of the toxicological potency of nine human pharmaceuticals on non-target species like fish. For this purpose, in vitro assays using fish cells were chosen as they have the advantage of minimising animal use, allowing the testing of a wide range of different chemicals and concentrations, and determining the cell or organ specific mechanism of toxicity (Eisenbrand et al., 2002). Considering the involvement of the liver in detoxification, drugs were tested on two complementary hepatocyte models: the PLHC-1 cell line (Ryan and Hightower, 1994), and the primary rainbow trout hepatocytes 
(PRTH) which maintain in vivo-like enzymatic activity during 3 to 8 days (Ferraris et al., 2002).

The nine tested drugs were parent compounds of human pharmaceuticals from seven different pharmaceutical classes. The two hypolipemiants, Fenofibrate (FF) and Clofibrate (CF) were chosen because of their wide use in Europe and France respectively. The diagnostic agent, Gadolinium Chloride $\left(\mathrm{GdCl}_{3}\right)$, usually used in magnetic radio imaging (MRI), was tested because of the presence of anomalies in coastal waters and rivers in the south of France due to human use (Elbaz-Poulichet et al., 2002). The other tested drugs were chosen according to their wide use in France. Antidepressants were represented by Fluoxetine (FX), Non Steroidian Anti Inflammatory Drugs (NSAID) by Diclofenac (DiCF), $\beta$-blockers by Propranolol (POH), antiepileptics by Carbamazepine (CBZ) and antibiotics by Sulfamethoxazole (SFX) and Amoxicillin (AMX). In mammals most of these drugs are metabolised by cytochromes P450 (CYP) enzymes and three of them, FF, CF and FX, induce oxidative stress in human and rodent cells (Qu et al., 2001; Slamon and Pentreath, 2000). In the present study, the toxicological potency of these pharmaceuticals on fish cells was evaluated by cytotoxicity measurement, reactive oxygen species production and CYP1A activity on two fish hepatocyte models PLHC-1 and PRTH. 


\section{Materials and methods}

\section{$2.1 \quad$ Chemicals}

All chemicals were purchased from Sigma (France). Stock solutions of organic compounds were prepared in dimethyl sulfoxyde (DMSO) at 200 times the desired concentration. Concerning $\mathrm{GdCl}_{3}$, stock solutions were prepared in ultra-pure water at 100 times the desired final concentration.

\subsection{Animals}

Immature rainbow trout (Onchorynchus mykiss) were obtained from a local hatchery (INRA, Gournay-sur-Aronde, France). Fish were kept in tanks with aerated charcoal filtered tap-water at a temperature of $15^{\circ} \mathrm{C}$. Rainbow trout were fed with commercial fish food and acclimatised to laboratory conditions for a minimum of 2 weeks before use in the experiments.

\subsection{Trout hepatocyte isolation and culture}

Hepatocytes were collected by the perfusion method described by Gagne et al. (1995). In brief, rainbow trout were killed and the abdominal cavity was rapidly opened in aseptical conditions. The liver was perfused via the hepatic portal vein with about $30 \mathrm{ml}$ of perfusion solution: Dulbecco's Phosphate Buffered Saline (D-PBS) without calcium and magnesium (Sigma, France), albumin $0.1 \%$ and sodium citrate $10 \mathrm{mM}$ adjusted to $\mathrm{pH} 7.5$. The liver was dissected, cut in small pieces and transferred to a sterile dissociation solution: D-PBS with calcium and magnesium (Gibco, France), albumin $0.5 \%, \mathrm{NaCl} 120 \mathrm{mM}$ and sodium citrate $15 \mathrm{mM}$. After $30 \mathrm{~min}$ agitation at $4{ }^{\circ} \mathrm{C}$, the mix was passed 3 times through sterile $63 \mu \mathrm{m}$ nylon gauze. The cell suspension was washed 3 times by centrifugation at $2000 \mathrm{~g}, 4{ }^{\circ} \mathrm{C}$ during 4 min until the supernatant became clear. The supernatant was then removed and the cells resuspended in $5 \mathrm{ml}$ of D-PBS with calcium and magnesium. The cell viability was 
determined using trypan blue exclusion test and was always found above $90 \%$. Freshly isolated hepatocytes were seeded in 48 well untreated microplates (Iwaki, Japan) at a density of $15.10^{5}$ cells per well and cultured at $15^{\circ} \mathrm{C}$ in M199 cell culture medium (Sigma, France) supplemented with $5 \%$ decomplemented fotal calf serum, penicillin and streptomycin (50 $\mathrm{U} / \mathrm{ml}$ ) and $10 \mathrm{mM}$ hepes. Cells were left to incubate $24 \mathrm{hrs}$ before exposure to chemicals.

\subsection{Hepatocyte cell line}

The PLHC-1 cell line, obtained from the American Type Culture Collection (ATCC CRL 2406), is derived from the hepatocellular carcinoma of the topminnow Poeciliopsis lucida (Ryan and Hightower, 1994). They were routinely grown at $30{ }^{\circ} \mathrm{C}$ in minimum essential medium with Earle's salts (E-MEM, Gibco, France) supplemented with $10 \%$ (v/v) decomplemented fœetal calf serum, $1 \%$ v/v non-essential amino acids (Gibco, France) and 50 $\mathrm{U}^{-1} \mathrm{ml}^{-1}$ of penicillin and streptomycin in a $5 \% \mathrm{CO}_{2}$ humidified atmosphere. For chemical testing, cells were sub-cultured and seeded in 96-well plate (TPP, Switzerland) at a rate of

$5.10^{5}$ cells per well and left to grow up to confluency before adding chemicals.

\subsection{Chemical exposure}

Chemicals dissolved either in DMSO or in ultra-pure water were added to the medium so that the final solvent concentration was always 0.5 or $1 \% \mathrm{v} / \mathrm{v}$ respectively. Control wells received the solvent only (carrier control). After exposure to pharmaceuticals and controls for $24 \mathrm{hrs}$, both cell models were subjected to MTT and EROD assays. Initially, the tested concentrations were chosen according to the limit of solubility of each drug. Afterwards, a range-finding study was conducted to determine the pharmaceuticals exposure that allowed the modelling of the dose-effect curves. 


\subsection{MTT assay}

Cytotoxic concentrations were determined by the MTT reduction test adapted from the Mosmann's procedure (Mosmann, 1983). After chemical exposure the medium was removed and cells were incubated for $3 \mathrm{hrs}$ with $0.5 \mathrm{mg} \cdot \mathrm{ml}^{-1}$ MTT dissolved in RPMI medium. MTT was cleared out and the formazan salts were solubilized in $100 \mu 1$ isopropanol. Plates were read at $570 \mathrm{~nm}$ against a $660 \mathrm{~nm}$ reference wavelength on a microplate reader (BioTek Instruments, France). Cell viability was expressed as a percentage of the corresponding control value.

\subsection{EROD assay}

EROD activity in intact cells was assessed as previously described by Hahn et al. (1996) and Kennedy et al. (1993). In short, medium was removed and replaced by $100 \mu$ or $300 \mu \mathrm{l}$ of culture medium containing $2 \mu \mathrm{M}$ of 7 -ethoxyresorufin in 96 and 48 -well microplates respectively. Kinetics of resorufin production were monitored during $15 \mathrm{~min}$ in a microplate fluorimeter (Victor ${ }^{2}$, Perkin Elmer, France) at $530 \mathrm{~nm}$ and $590 \mathrm{~nm}$ excitation and emission wavelengths, respectively, at $30^{\circ} \mathrm{C}$ for PLHC-1 cells and at room temperature for PRTH. In each test, the positive control for EROD induction was $1 \mu \mathrm{M} \mathrm{BaP}$. Then, the wells were washed with PBS and total cellular proteins were determined with the fluorescamine assay (Lorenzen and Kennedy, 1993), using bovine serum albumin (BSA) as a standard. The EROD activity was expressed in pmol of resorufine per minute and per mg of proteins $\left(\right.$ pmol.min $\left.\mathrm{min}^{-1} \cdot \mathrm{mg}^{-1}\right)$.

\subsection{Reactive oxygen species (ROS) generation}

The production of ROS in PLHC-1 cells was determined by using the method of LeBel et al. (1983) with slight modifications. Cells were washed three times with PBS and incubated with $1 \mu \mathrm{l}$ of $40 \mu \mathrm{M}$ DCFH-DA (dichlorofluorescamin diacetate) diluted in PBS 
supplemented with $10 \mathrm{mM}$ glucose (PBS-Gluc). After $30 \mathrm{~min}$ incubation at $30^{\circ} \mathrm{C}$, the cells monolayers were washed twice with PBS and exposed to pharmaceuticals in PBS-Gluc. The fluorescence of oxidised DCFH was measured immediately and every hour during 5 hrs with a microplate fluorimeter (Victor ${ }^{2}$, Perkin Elmer, France), at excitation and emission wavelengths of $490 \mathrm{~nm}$ and $535 \mathrm{~nm}$ respectively. Positive control was obtained using $5 \mu \mathrm{M}$ $\mathrm{H}_{2} \mathrm{O}_{2}$. The kinetics allowed the determination of the time of toxic exposure at which maximum of ROS production occurred. Results were expressed as a percentage of the basal fluorescence in the carrier control wells.

\subsection{Data analysis}

The toxicity of the tested substances was expressed by the concentration of drug required to observe $50 \%$ of the maximum effect $\left(\mathrm{EC}_{50}\right) . \mathrm{EC}_{50}$ for MTT reduction and EROD inhibition were calculated using the Microsoft Excell Regtox 6.3 macro (Vindimian et al., 1983) freely available at www.perso.wanadoo.fr/eric.vindimian/en_index.html. All experimental data were expressed as means \pm standard deviation of 3 (PLHC-1) and 4 replicates (PRTH). Data were subjected to statistical analysis by one way analysis of variance (ANOVA) followed by Dunnett's bilateral posthoc test. A value of $p<0.05$ was considered significant. The SPSS ${ }^{\mathrm{TM}}$ software version 10.1 for Windows was used for the statistical analysis. All results are representative of at least three independent experiments. 


\section{Results}

\subsection{Cytotoxicity}

The MTT EC 50 values and the concentrations of pharmaceuticals tested on PRTH and PLHC-1 are summarised in Table 1. The levels of toxicity varied not only according to the substances tested but also to the biological model.

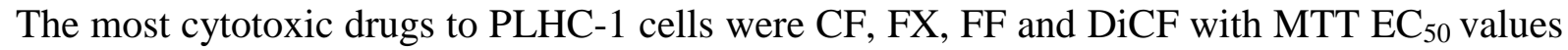
of $2 \mu \mathrm{M}, 5 \mu \mathrm{M}, 9 \mu \mathrm{M}$ and $19 \mu \mathrm{M}$ respectively. On PRTH, the most cytotoxic drugs were FF, FX and CF with $\mathrm{EC}_{50}$ of $53 \mu \mathrm{M}, 66 \mu \mathrm{M}$ and $133 \mu \mathrm{M}$ respectively. For the other drugs, the $\mathrm{EC}_{50}$ values ranged from $85 \mu \mathrm{M}(\mathrm{POH})$ to $651 \mu \mathrm{M}(\mathrm{CBZ})$ on PLHC-1 and from $453 \mu \mathrm{M}$ (POH) to $963 \mu \mathrm{M}(\mathrm{GdCl} 3)$ on PRTH. Among the tested compounds, only the antibiotic AMX showed no cytotoxicity neither on PLHC-1 nor on PRTH. For the sulfamide antibiotic, SFX, cytotoxicity appeared only at the highest tested concentration. The overall comparison of the MTT $\mathrm{EC}_{50}$ values obtained for both models showed that PRTH were somewhat less sensitive than PLHC-1 to the pharmaceuticals cytotoxicity. Indeed, $\mathrm{EC}_{50}$ values on PRTH cells were from $5(\mathrm{FF}, \mathrm{POH})$ to $50(\mathrm{CF})$ orders of magnitude higher than those obtained for PLHC-1.

\subsection{Effect on EROD activity}

None of the tested drugs induced EROD in PLHC-1 hepatocytes due to a low basal EROD expression, only induction could be studied in these cells. On the contrary, PRTH allowed the detection of both induction and inhibition of EROD activity. As seen in Fig.1-4, different patterns of responses were observed. First a significant increase of EROD activity was observed in cells exposed to sublethal concentration of the beta-blocker POH (Fig. 1). Secondly, all substances, except AMX (Fig.4.), were able to decrease EROD activity whether at sublethal or lethal concentrations. The specific EROD inhibition, at clearly sublethal concentrations, appeared after exposure to DiCF, SFX and CBZ (Fig. 2) whereas this 
inhibition appeared to be less specific in the case of FF and CF (Fig. 3). Finally the EROD inhibition was concommitant with cytotoxicity in cells exposed to $\mathrm{FX}, \mathrm{GdCl}_{3}$ and $\mathrm{POH}$ (Fig.4).

\subsection{ROS production}

Three (FF, CF and FX) out of nine pharmaceuticals induced significant ROS production in PLHC-1 cells (Fig.5). FF was the most efficient in inducing an oxidant effect as, within the first hour of exposure, ROS production increased in a dose-dependant manner $(7.8-30 \mu \mathrm{M})$ up to 4 times the basal level at the highest concentration tested. The ROS level, after CF and FX exposure, was weaker as it reached only about 1.5 times the basal value after a $4 \mathrm{hrs}$ exposure at 1000 and $36 \mu \mathrm{M}$ respectively. 


\section{Discussion}

The purpose of this work was to evaluate the acute and sublethal effects of nine pharmaceuticals on two fish hepatocyte models, PLHC-1 and PRTH. The main outcomes are: (1) eight of the nine tested drugs were cytotoxic on both cell models; (2) for FF, CF and FX, oxidative stress was involved in cytotoxicity process; (3) specific EROD inhibition was observed with DiCF, CBZ and SFX, and, to a lesser extend, by FF and CF; (4) POH significantly induced EROD activity.

Our results suggest that most of the tested drugs $\left(\mathrm{FF}, \mathrm{CF}, \mathrm{FX}, \mathrm{POH}, \mathrm{DiCF}, \mathrm{GdCl}_{3}\right.$ ) were more toxic to PLHC-1 than to PRTH (Table 1). This difference could reflect the different sensitivity of cell lines versus primary hepatocytes or the differences in the ability of each model to metabolise human drugs as PRTH can inactivate toxicants (via metabolisation) and develop defence against oxidants (Ferraris et al., 2002). Only CBZ was more toxic in PRTH, probably because of its transformation into active metabolites CBZ-E and/or arene oxide (Masubuchi et al., 2001; Tabatabaei et al., 1997). Overall, although no comparable data are available in fish for all the tested substances, MTT $\mathrm{EC}_{50}$ measured in this study are in the same range and sometimes slightly more sensitive than cytotoxic concentrations previously described in human and rat. For example, the $\mathrm{MTT}^{\mathrm{EC}_{50}}$ found in human and rat hepatocytes range between 176 and $341 \mu \mathrm{M}$ for POH (Ponsoda et al., 1995), and between 61 and $64 \mu \mathrm{M}$ for $\mathrm{DiCF}$ (Bort et al., 1999b). In the same way the $\mathrm{EC}_{50} \mathrm{~s}$ obtained with the acute Daphnia magna test for FX (Brooks et al., 2003), POH (Huggett et al., 2002), CBZ and DiCF (Cleuvers, 2003; Ferrari et al., 2003), are in the same order of magnitude as our cytotoxicity results. In parallel, all the tested drugs except AMX, interacted with CYP1A metabolism pathways in rainbow trout hepatocytes through an induction or an inhibition of the EROD 
activity. Such effects are of environmental concern, as alteration of CYP1A activity has been shown to affect xenobiotic metabolism and toxicity in rainbow trout (Hawkins et al., 2002).

The hypolipemiants FF and CF belong to peroxisome proliferators (PPs). This group of structurally diverse compounds is known to bind and activate the peroxisome proliferatoractivated receptors (PPARs). Among the three main PPARs isoforms so far identified (PPAR $\alpha$, PPAR $\beta$, PPAR $\gamma$ ) PPAR $\alpha$ seems to mediate the hypotriglyceridemic effect of hypolipemiants by inducing high rates of mitochondrial and peroxisomal $\beta$-oxidation of lipids in rodents and human (Mukherjee et al., 1994). Such activation leads to pro-oxidant effect via the increase of $\mathrm{H}_{2} \mathrm{O}_{2}$ production rate in mice (Qu et al., 1999; Qu et al., 2001). In salmon hepatocytes the activation of PPAR $\gamma$ (Andersen et al., 2000) after exposure to fibrates, mediates enzymatic response like the increase of peroxisomal acyl-co-enzyme-A activity (Ruyter et al., 1997). In addition FF has been described to be more efficient than CF in inducing peroxisome proliferation in rat hepatocytes and in increasing characteristic peroxisomal activities such as carnitine acetyl transferase (CAT) or CYP4A1 activities (Hildebrand et al., 1999). In our experiments, FF rapidly induced ROS generation whereas its homologue was much less efficient regarding ROS production (Fig. 3). Thus, our results support the idea that CF and FF activate PPARs or at least peroxisomal activities in fish cells. This finding is particularly interesting because differences between species have been reported about sensitivity towards peroxisome proliferation. Indeed dogs and humans are regarded as insensitive species (Ashby et al., 1994) whereas rat (Hildebrand et al., 1999) and fish (Ruyter et al., 1997) would be sensitive ones.

ROS, such as $\mathrm{H}_{2} \mathrm{O}_{2}$, are known to specifically inhibit CYP enzymes mainly at the transcriptional level by inhibiting the mRNA synthesis (Barker et al., 1994; Risso-de Faverney et al., 2000). Sometimes this CYP inhibition also occurs at the posttranscriptional 
level by the increasing the degradation of mRNA (Delaporte and Renton, 1997) or at the protein level when toxicants act directly as mechanism-based inhibitors (suicide substrate) (Watson et al., 1995),. Moreover Jiao and Zhao(2002) showed that FF inhibited the growth of human HepG2 cells in a dose-related manner through the generation of oxidative stress. Consequently, it is very likely that, in fish cells, specific EROD inhibition and loss of cell viability by FF and CF are due to ROS overproduction through PPAR activation.

The antidepressant FX was among the most cytotoxic drugs in both cellular models and induced ROS production in PLHC-1. The resulting hypothesis that, in fish hepatocytes, FX cytotoxicity is mediated through oxidative stress is consistent with the previous study of Slamon and Pentreath (2000) who showed the involvement of antioxidants such as glutathion (GSH) in the protection of rat glioma C6 cells and human astrocytes cell line against this antidepressant.

The DiCF exerted a cytotoxic effect at $500 \mu \mathrm{M}$, which is in agreement with previous results on rat or human hepatocytes (Bort et al., 1999b). The mechanism of DiCF cytotoxicity is not fully understood but there is some evidence that both uncoupling of mitochondrial oxidative phosphorilation and CYP-mediated metabolism are involved in human and rat hepatocytes acute toxicity(Bort et al., 1999a). In our study, we observed a clear inhibition of EROD at $36 \mu \mathrm{M}$, suggesting a specific interaction between DiCF or its metabolites with this enzyme in rainbow trout, but this interaction is apparently not related to the cytotoxicity of DiCF to PRTH. Although the mechanism of CYP1A inhibition by NSAID is not known, the ability of these drugs to decrease 3 methylcholanthrene-induced EROD activity has been reported in rat hepatocytes (Pappas et al., 1998).

Among the tested drugs, the $\beta$-adrenergic receptor antagonist, $\mathrm{POH}$, was the only EROD inducer in PRTH. To our knowledge, there is no report on the ability of this compound either to bind and activate the aryl hydrocarbon receptor (Ah-R), or to induce the CYP1A 
enzyme. Nevertheless, the observed EROD induction might be related to $\mathrm{POH}$ metabolism by CYP1A previously described in $\beta$-naphtoflavone-induced rat hepatic microsomes ( $\mathrm{Li}$ and Zeng, 2000).

In human lymphocytes, $\mathrm{CBZ}$ is metabolised by CYP dependant monooxygenase into 10,11-epoxide CBZ (CBZ-E), an active and toxic metabolite which is then transformed into the corresponding diol by an epoxide hydrolase (Tabatabaei et al., 1997). It was clearly established that in some cases, clinical toxicities were associated with CBZ-E production. CBZ-E is also found in mice, dog, rat and rabbit (Rambeck et al., 1990), thus representing a metabolic pathway common to these species. In human and rat, CYPs involved in CBZ metabolism are diverse and include CYP1A2, CYP2C8, CYP3A4, CYP2D and CYP1A2 (Masubuchi et al., 2001; Mesdjian et al., 1999). Recently, it has been shown that CBZ biotransformation into arene-oxide intermediates by CYP2D in rat and CYP1A2 in humans results in inactivation of the enzymes themselves probably via the covalent binding of these metabolites with CYP proteins (Masubuchi et al., 2001). Therefore, the strong and specific CYP1A inhibition observed in our study results likely from the CBZ biotransformation into reactive metabolites and thus suggests the ability of fish cells to metabolise this drug.

The contrast agent $\mathrm{GdCl}_{3}$ has been described as a CYP inhibitor in vivo in human and rodents (Badger et al., 1997; Palasz and Czekaj, 2000). In goldfish, it has been shown to accumulate in the liver and to induce antioxidant enzymes after 10 days of exposure (Chen et al., 2000). Our results did not correlate with those data as $\mathrm{GdCl}_{3}$ neither inhibited specifically EROD activity, nor induced oxidative stress in fish cells. This suggests a low sensitivity of the fish hepatocytes PRTH and PLHC-1 to this rare earth element.

Although the sulfonamide antibiotic SFX was not cytotoxic enough to calculate $\mathrm{EC}_{50}$ values, it inhibited EROD activity right from $125 \mu \mathrm{M}$. In human liver microsomes, SFX is described as a selective inhibitor of CYP2C8 and CYP2C9 that would loose selectivity for the 
CYP isoforms at concentrations higher than $500 \mu \mathrm{M}$ (Wen et al., 2002). As a result, SFX must be a selective inhibitor of CYP1A enzymes in fish hepatocytes. Concerning the ampicillin antibiotic, AMX is not described as a potential toxicant in literature and, accordingly, it didn't exert any particular effect on fish hepatocytes.

In summary, this study raises three interesting observations. First, a classification of human drugs from the least to the most cytotoxic to fish hepatocytes was established: the two antibiotics (AMX and SFX) showed no cytotoxic effect, whereas the hypolipemiants (CF and FF) and the antidepressant (FX) were the most cytotoxic and induced oxidative stress at sublethal concentrations. Secondly, the majority of the human drugs caused a specific EROD inhibition. This may have relevance to the use of CYP1A as a biomarker for aquatic pollution. In a multipollution context, considering the involvement of CYP1A in detoxification pathways, its inhibition could increase the toxicity of the other toxicants. Thirdly, if the effective concentrations were comparable with ecotoxicity tests found in the literature, they remain much higher (one thousand times) than those found in the environment. Nevertheless, before coming to a conclusion about the absence of toxicity in fish exposed to contaminated waters in the environment, the in vivo potential adverse effects of drugs to fish under chronic exposure should be assessed.

AKNOWLEDGEMENTS This work was partly supported by the French National Program for Ecotoxicology (PNETOX) and by the "Budget Civil de Recherche et Développement" (BCRD Grant 01-111).

\section{References}


Andersen, O., Eijsink, V.G., Thomassen, M., 2000. Multiple variants of the peroxisome proliferator-activated receptor (PPAR) gamma are expressed in the liver of atlantic salmon (Salmo salar). Gene 255, 411 - 418.

Andreozzi, R., Marotta, R., Pinto, G., Pollio, A., 2002. Carbamazepine in water: persistence in the environment, ozonation treatment and preliminary assessment on algal toxicity. Water. Res. 36, 2869 - 2877.

Ashby, J., Brady, A., Elcombe, C.R., Elliott, B.M., Ishmael, J., Odum, J., Tugwood, J.D., Kettle, S., Purchase, I.F., 1994. Mechanistically-based human hazard assessment of peroxisome proliferator-induced hepatocarcinogenesis. Hum. Exp. Toxicol. 13 Suppl 2, S1-117.

Badger, D.A., Kuester, R.K., Sauer, J.M., Sipes, I.G., 1997. Gadolinium chloride reduces cytochrome P450: relevance to chemical-induced hepatotoxicity. Toxicology 121, 143 $-153$.

Barker, C.W., Fagan, J.B., Pasco, D.S., 1994. Down-regulation of P4501A1 and P4501A2 mRNA expression in isolated hepatocytes by oxidative stress. J. Biol. Chem. 269, $3985-3990$.

Bort, R., Mace, K., Boobis, A., Gomez-Lechon, M.J., Pfeifer, A., Castell, J., 1999a. Hepatic metabolism of diclofenac: role of human CYP in the minor oxidative pathways. Biochem. Pharmacol. 58, 787 - 796.

Bort, R., Ponsoda, X., Jover, R., Gomez-Lechon, M.J., Castell, J.V., 1999b. Diclofenac Toxicity to Hepatocytes: A Role for Drug Metabolism in Cell Toxicity. J. Pharmacol. Exp. Ther. 288, $65-72$.

Brooks, B.W., Turner, P.K., Stanley, J.K., Weston, J.J., Glidewell, E.A., Foran, C.M., Slattery, M., La Point, T.W., Huggett, D.B., 2003. Waterborne and sediment toxicity of fluoxetine to select organisms. Chemosphere 52, 135 - 142. 
Chen, Y., Cao, X.D., Lu, Y., Wang, R., 2000. Effects of rare earth metal ions and their EDTA complexes on antioxydant enzymes of fish liver. Bull. Environ. Contam. Toxicol. 65, $357-365$.

Cleuvers, M., 2003. Aquatic ecotoxicity of pharmaceuticals including the assessment of combination effects. Toxicol. Lett. 142, 185 - 194.

Daughton, C.G., Ternes, T.A., 1999. Pharmaceuticals and personal care products in the environment: agents of subtle change? Environ. Health. Perspect. 107, 907 - 938.

Delaporte, E., Renton, K.W., 1997. Cytochrome P4501A1 and cytochrome P4501A2 are downregulated at both transcriptional and post-transcriptional levels by conditions resulting in interferon-alpha/beta induction. Life Sci. 60, 787 - 796.

Eisenbrand, G., Pool-Zobel, B., Baker, V., Balls, M., Blaauboer, B.J., Boobis, A., Carere, A., Kevekordes, S., Lhuguenot, J.C., Pieters, R., Kleiner, J., 2002. Methods of in vitro toxicology. Food Chem. Toxicol. 40, 193 - 236.

Elbaz-Poulichet, F., Seidel, J.L., Othoniel, C., 2002. Occurrence of an anthropogenic gadolinium anomaly in river and coastal waters of southern France. Water Res. 36, $1102-1105$.

Ferrari, B., Paxéus, N., Lo Giudice, R., Pollio, A., Garric, J., 2003. Ecotoxicological impact of pharmaceuticals found in treated wastewaters: study of carbamazepine, clofibric acid, and diclofenac. Ecotoxicological and environmental safety 55, 359 - 370.

Ferraris, M., Radice, S., Catalani, P., Francolini, M., Marabini, L., Chiesara, E., 2002. Early oxidative damage in primary cultured trout hepatocytes: a time course study. Aquat. Toxicol. 59, 283 - 296.

Gagne, F., Trottier, S., Blaise, C., Sproull, J., Ernst, B., 1995. Genotoxicity of sediment extracts obtained in the vicinity of a creosote-treated wharf to rainbow trout hepatocytes. Toxicol. Lett. 78, 175-82. 
Hahn, M.E., Woodward, B.L., J., S.J., 1996. Rapid assessmant of induced cytochrome P4501A protein and catalytic activity in fish hepatoma cells grown in multiwell plates: response to TCDD, TCDF and two planar PCBS. Environmental Toxicology and Chemistry 15, $582-591$.

Halling-Sorensen, B., Nors Nielsen, S., Lanzky, P.F., Ingerslev, F., Holten Lutzhoft, H.C., Jorgensen, S.E., 1998. Occurrence, fate and effects of pharmaceutical substances in the environment - a review. Chemosphere 36, 357 - 393.

Hawkins, S.A., Billiard, S.M., Tabash, S.P., Brown, R.S., Hodson, P.V., 2002. Altering cytochrome P4501A activity affects polycyclic aromatic hydrocarbon metabolism and toxicity in rainbow trout (Oncorhynchus mykiss). Environ. Toxicol. Chem. 21, 1845 1853.

Hildebrand, H., Schmidt, U., Kempka, G., Jacob, R., Ahr, H.J., Ebener, C., Goretzki, P.E., Bader, A., 1999. An in vitro model for peroxisome proliferation utilizing primary hepatocytes in sandwich culture. Toxicol In vitro 13, 265 - 273.

Huggett, D.B., Brooks, B.W., Peterson, B., Foran, C.M., Schlenk, D., 2002. Toxicity of select beta adrenergic receptor-blocking pharmaceuticals (B-Blockers) on aquatic organisms. Arch. Environ. Contam. Toxicol. 43, 229 - 235.

Jiao, H.L., Zhao, B.L., 2002. Cytotoxic effect of peroxisome proliferator fenofibrate on human HepG2 hepatoma cell line and relevant mechanisms. Toxicol. Appl. Pharmacol. 185, 172 - 179.

Kennedy, S.W., Lorenzen, A., James, C.A., Collins, B.T., 1993. Ethoxyresorufin-Odeethylase and porphyrin analysis in chicken embryo hepatocyte cultures with a fluorescence multiwell plate reader. Anal. Biochem. 211, 102 - 112. 
LeBel, C.P., Ischiropoulos, H., Bondy, S.C., 1983. Evaluation of the probe 2',7'-

dichlorofluorescin as an indicator of reactive oxygen species formation and oxidative stress. Chem. Res. Toxicol. 5, 227 - 231.

Li, X., Zeng, S., 2000. Stereoselective propranolol metablism in two drug induced in rat hepatic microsomes. World J. Gastroenterol. 6, 74 - 78.

Lorenzen, A., Kennedy, S.W., 1993. A fluorescence-based protein assay for use with a microplate reader. Anal. Biochem. 214, 346 - 348.

Masubuchi, Y., Nakano, T., Ose, A., Horie, T., 2001. Differential selectivity in carbamazepine-induced inactivation of cytochrome P450 enzymes in rat and human liver. Arch. Toxicol. 75, 538 - 543.

Mesdjian, E., Seree, E., Charvet, B., Mirrione, A., Bourgarel-Rey, V., Desobry, A., Barra, Y., 1999. Metabolism of carbamazepine by CYP3A6: a model for in vitro drug interactions studies. Life Sci. 64, 827 - 835.

Mosmann, T., 1983. Rapid colorimetric assay for cellular growth and survival: application to proliferation and cytotoxicity assays. J. Immunol. Methods 65, 55 - 63.

Mukherjee, R., Jow, L., Noonan, D., McDonnell, D.P., 1994. Human and rat peroxisome proliferator activated receptors (PPARs) demonstrate similar tissue distribution but different responsiveness to PPAR activators. J. Steroid Biochem. Mol. Biol. 51, 157 166.

Palasz, A., Czekaj, P., 2000. Toxicological and cytophysiological aspects of lanthanides action. Acta Biochim. Pol. 47, 1107 - 1114.

Pappas, P., Stehanou, P., Vasiliou, V., Marselos, M., 1998. Antiinflammatory agents andinducibility of hepatic drug metabolism. Eur. J. Drug Met. Pharma. 23, 457 - 460.

Ponsoda, X., Jover, R., Nunez, C., Royo, M., Castell, J.V., Gomez-Lechon, M.J., 1995. Evaluation of the cytotoxicity of 10 chemicals in human and rat hepatocytes and in 
cell lines: correlation between in vitro data and human lethal concentration. Toxicol. In vitro 9, 959 - 966.

Qu, B., Li, Q.T., Wong, K.P., Ong, C.N., Halliwell, B., 1999. Mitochondrial damage by the "pro-oxidant" peroxisomal proliferator clofibrate. Free Radic. Biol. Med. 27, 1095 1102.

Qu, B., Li, Q.T., Wong, K.P., Tan, T.M.C., Halliwell, B., 2001. Mechanism of clofibrate hepatotoxicity: mitochondrial damage and oxidative stress in hepatocytes. Free Radic. Biol. Med. 31, 659 - 669.

Rambeck, B., Salke-Treumann, A., May, T., Boenigk, H.E., 1990. Valproic acid-induced carbamazepine-10,11-epoxide toxicity in children and adolescents. Eur. Neurol. 30, 79 $-83$.

Risso-de Faverney, C., Lafaurie, M., Girard, J.P., Rahmani, R., 2000. The nitroxide stable radical tempo prevents metal-induced inhibition of CYP1A1 expression and induction. Toxicol. Lett. 111, 219 - 227.

Ruyter, B., Andersen, O., Dehli, A., Ostlund Farrants, A.K., Gjoen, T., Thomassen, M.S., 1997. Peroxisome proliferator activated receptors in Atlantic salmon (Salmo salar): effects on PPAR transcription and acyl-CoA oxidase activity in hepatocytes by peroxisome proliferators and fatty acids. Biochim. Biophys. Acta. 1348, 331 - 338.

Ryan, J.A., Hightower, L.E., 1994. Evaluation of heavy-metal ion toxicity in fish cells using a combined stress protein and cytotoxicity assay. Environ. Toxicol. Chem. 13, 1231 1240.

Seiler, J.P., 2002. Pharmacodynamic activity of drugs and ecotoxicology - can the two be connected? Toxicol. Lett. 131, $105-115$.

Slamon, N.D., Pentreath, V.W., 2000. Antioxidant defense against antidepressants in C6 and 1321N1 cells. Chem. Biol. Interact. 127, 181 - 199. 
Tabatabaei, A.R., Thies, R.L., Farrell, K., Abbott, F.S., 1997. A rapid in vitro assay for evaluation of metabolism-dependent cytotoxicity of antiepileptic drugs on isolated human lymphocytes. Fundam. Appl. Tox. 37, 181 - 189.

Ternes, T., 1998. Occurrence of drugs in German sewage treatment plants and rivers. Water Res. 32, 3245 - 3260.

Vindimian, E., Robaut, C., Fillion, G., 1983. A method for cooperative and non cooperative binding studies using non linear regression analysis on a microcomputer. J. Appl. Biochem. 5, 261 - 268.

Watson, D.E., Menard, L., Stegeman, J.J., Digiulio, R.T., 1995. Aminoanthracene is a mechanism-based inactivator of CYP1A in channel catfish hepatic issue. Toxicol. Appl. Pharmacol. 135, 208 - 215.

Wen, X., Wang, J.S., Backman, J.T., Laitila, J., Neuvonen, P.J., 2002. Trimethoprim and sulfamethoxazole are selective inhibitors of CYP2C8 and CYP2C9, respectively. Drug Metab. Dispos. 30, $631-635$. 


\section{Figures}

Fig. 1. Specific induction of EROD activity and viability of primary rainbow trout (PRTH) hepatocytes after $24 \mathrm{hrs}$ of exposure to propranolol $(\mathrm{POH})$. Values are means \pm Standard Deviation.

${ }^{a}$ Significant difference from basal EROD activity $(\mathrm{p}<0.05)$.

${ }^{\mathrm{b}}$ Significant difference from the positive control of cell viability $(\mathrm{p}<0.05)$.

Fig. 2. Specific inhibition of EROD activity at sublethal concentrations on primary rainbow trout (PRTH) hepatcoytes after 24 hours of exposure. Values are means \pm Standard Deviation. ${ }^{a}$ Significant difference from basal EROD activity $(\mathrm{p}<0.05)$.

${ }^{\mathrm{b}}$ Significant difference from the positive control of cell viability $(\mathrm{p}<0.05)$.

Fig.3. Basal EROD inhibition and cell viability of primary rainbow trout (PRTH) hepatocytes after $24 \mathrm{hrs}$ of exposure to the two hypolipemiants clofibrate (CF) and fenofibrtae (FF). Values are means \pm Standard Deviation.

${ }^{a}$ Significant difference from basal EROD activity $(\mathrm{p}<0.05)$.

${ }^{\mathrm{b}}$ Significant difference from the positive control of cell viability $(\mathrm{p}<0.05)$.

Fig.4. Pharmaceuticals without specific effect on the EROD activity at sublethal concentrations on primary rainbow trout (PRTH) hepatcoytes after 24 hours of exposure: cytotoxic and not cytotoxic ones. Values are means \pm Standard Deviation.

${ }^{a}$ Significant difference from basal EROD activity $(\mathrm{p}<0.05)$.

${ }^{\mathrm{b}}$ Significant difference from the positive control of cell viability $(\mathrm{p}<0.05)$.

Fig. 5. ROS production on PLHC-1 cells after $1 \mathrm{hr}$ of exposure for fenofibrate (FF) and after $4 \mathrm{hrs}$ of exposure for clofibrate (CF) and fluoxetine (FX). Times of exposure were chosen after the study of the kinetics of ROS production for each compound during 5 hours, and correspond to the time with the optimum of ROS production. The six other drugs ( $\mathrm{POH}$, SFX, CBZ, $\mathrm{GCl}_{3}, \mathrm{AMX}, \mathrm{DiCF}$ ) didn't show any ROS production. Values are means \pm Standard Deviation.

* Significant difference from control $(\mathrm{p}<0.05)$. 
EROD activity

Cell viability

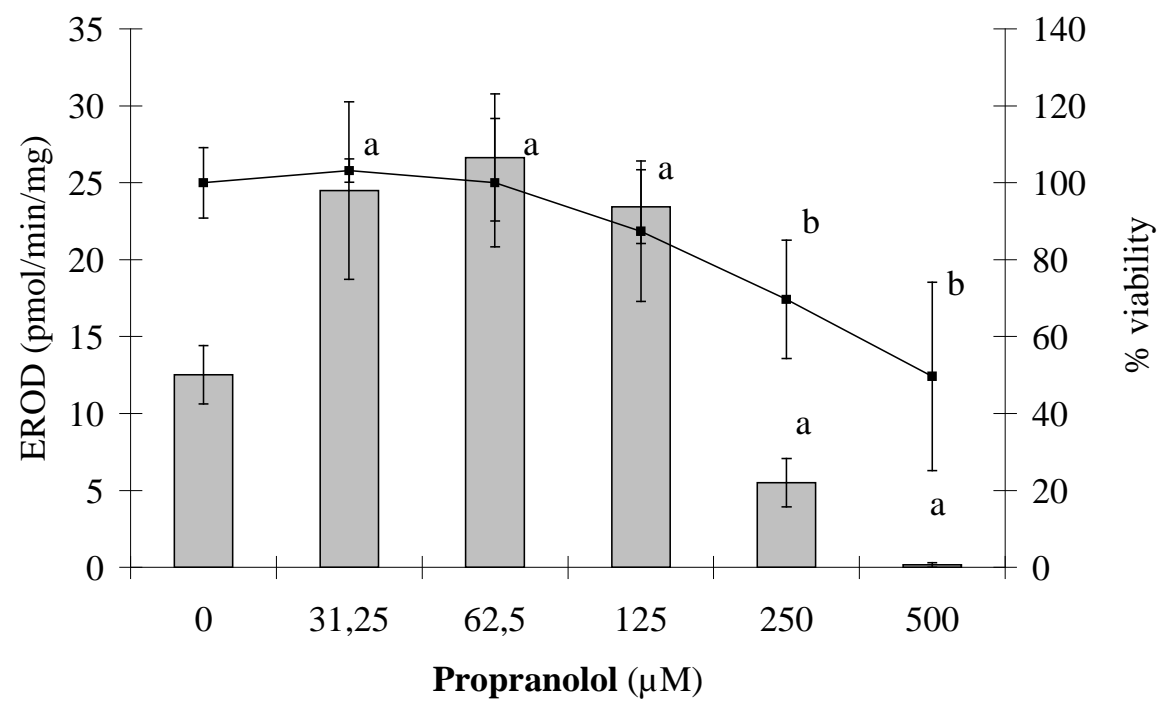

Fig.1. 


\section{EROD activity}

Cell viability
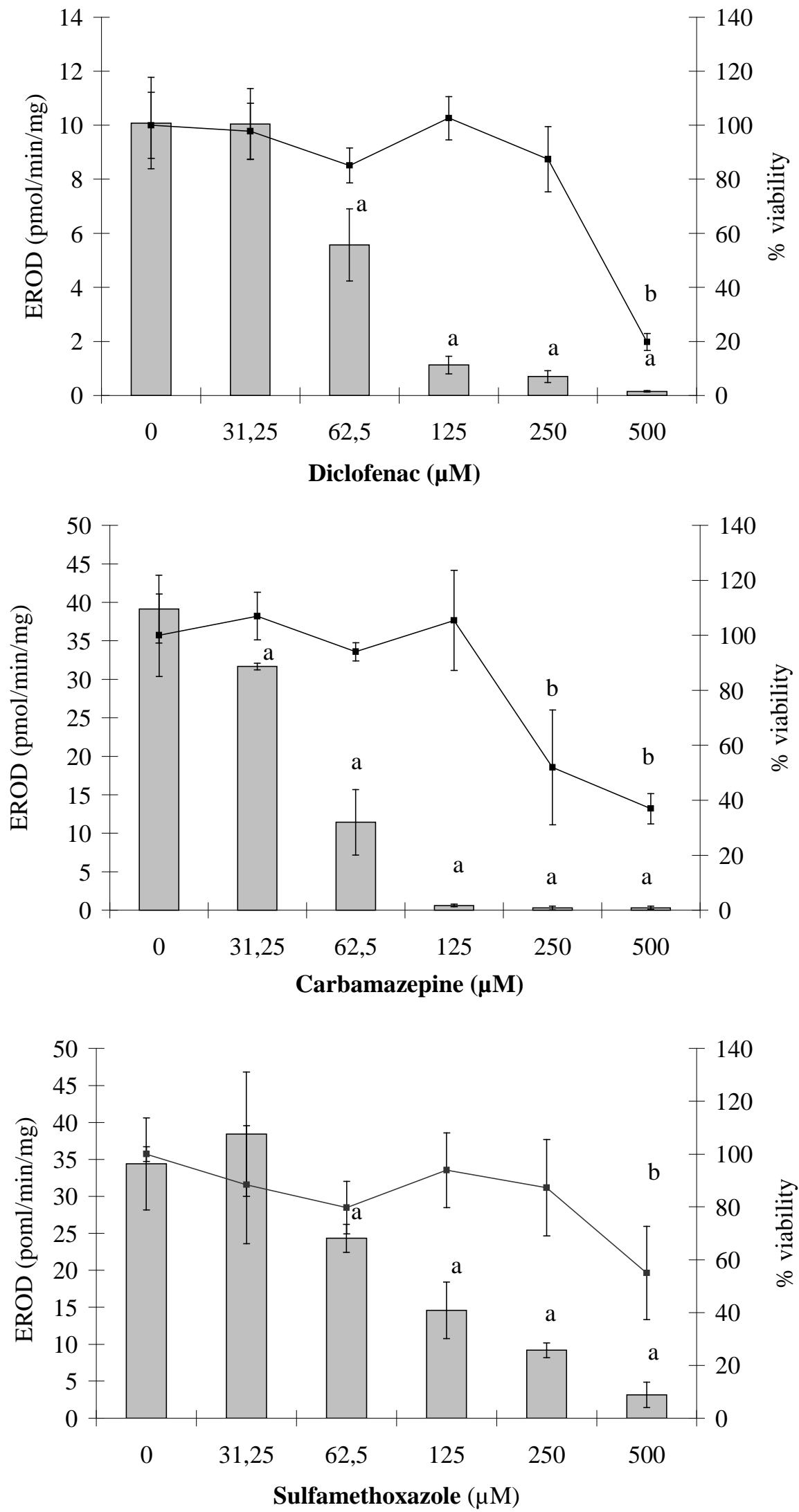

Fig. 2. 

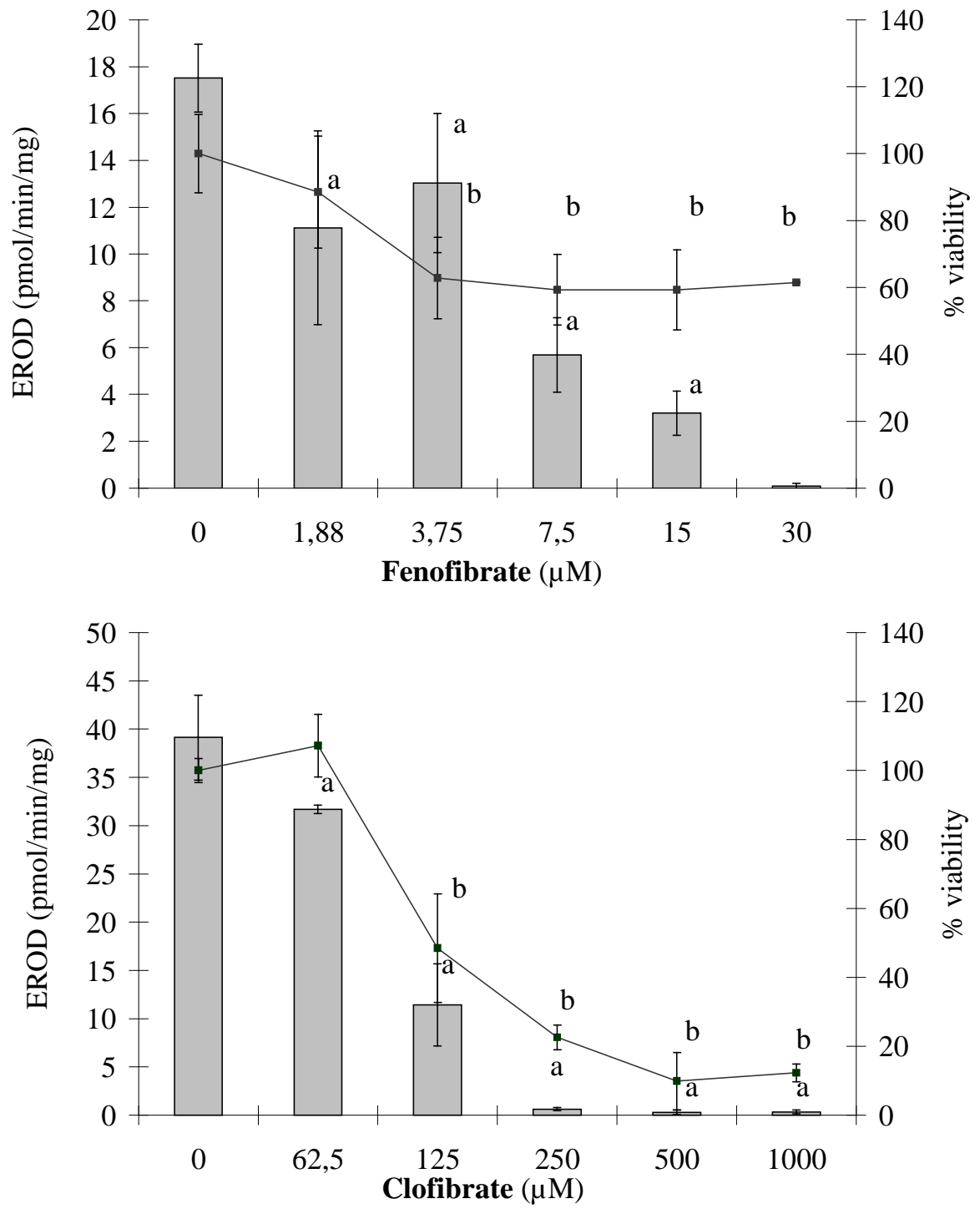

Fig. 3. 


\section{EROD activity}

Cell viability

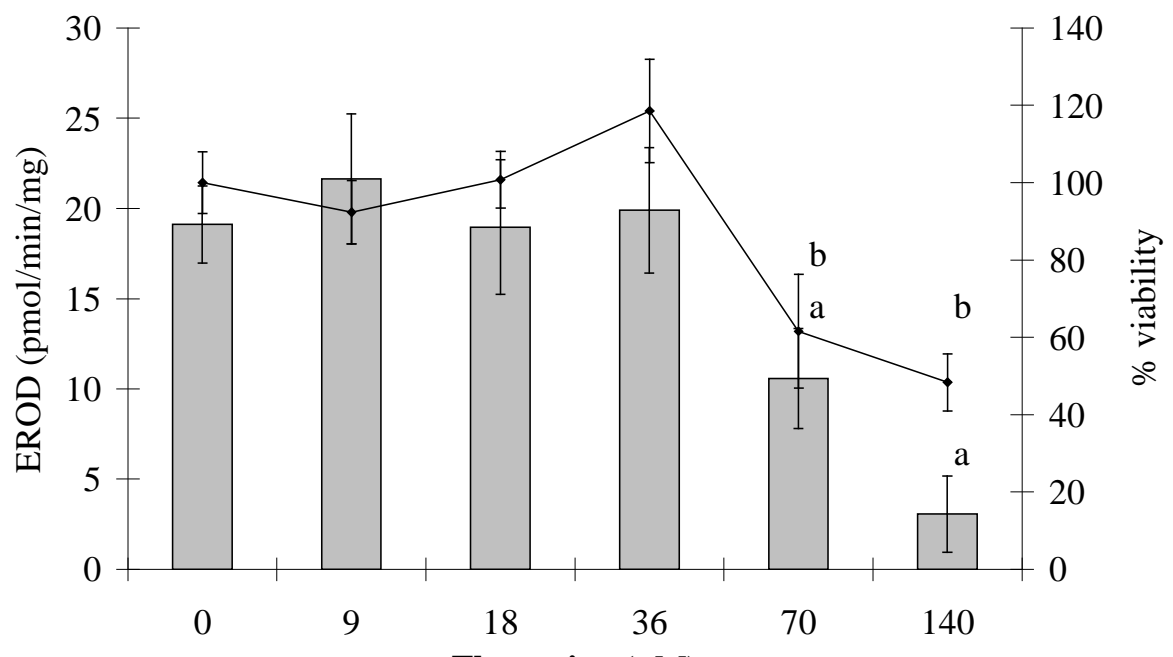

Fluoxetine $(\mu \mathrm{M})$

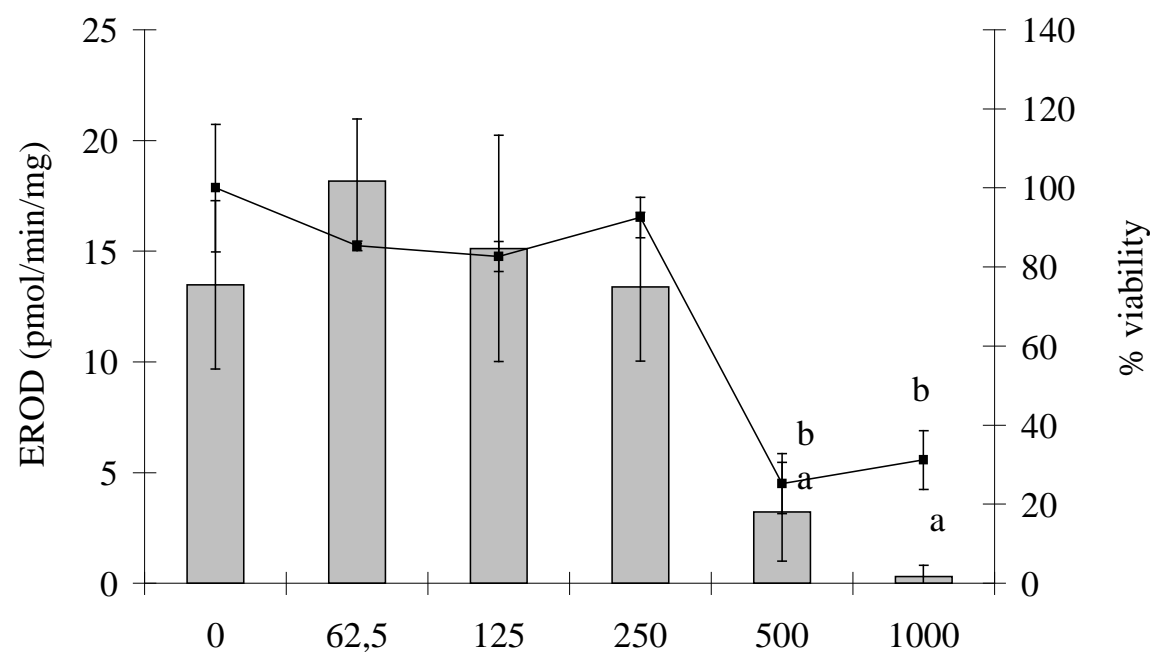

Gadolinium chlorhyde $(\mu \mathrm{M})$

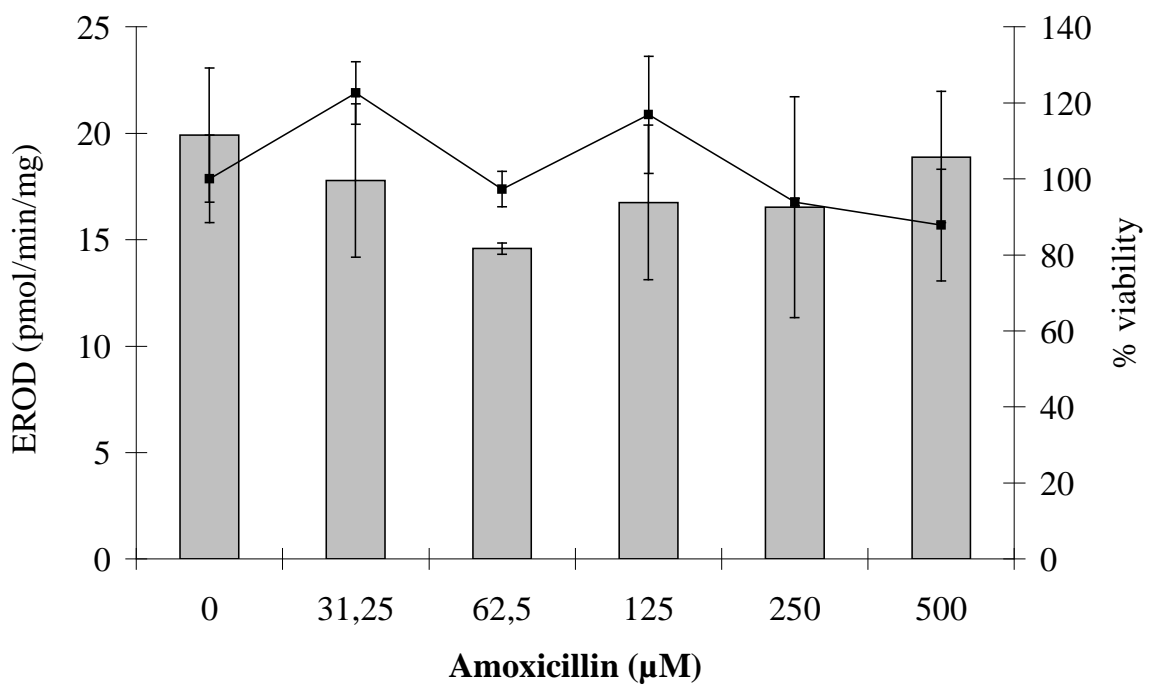

Fig. 4. 

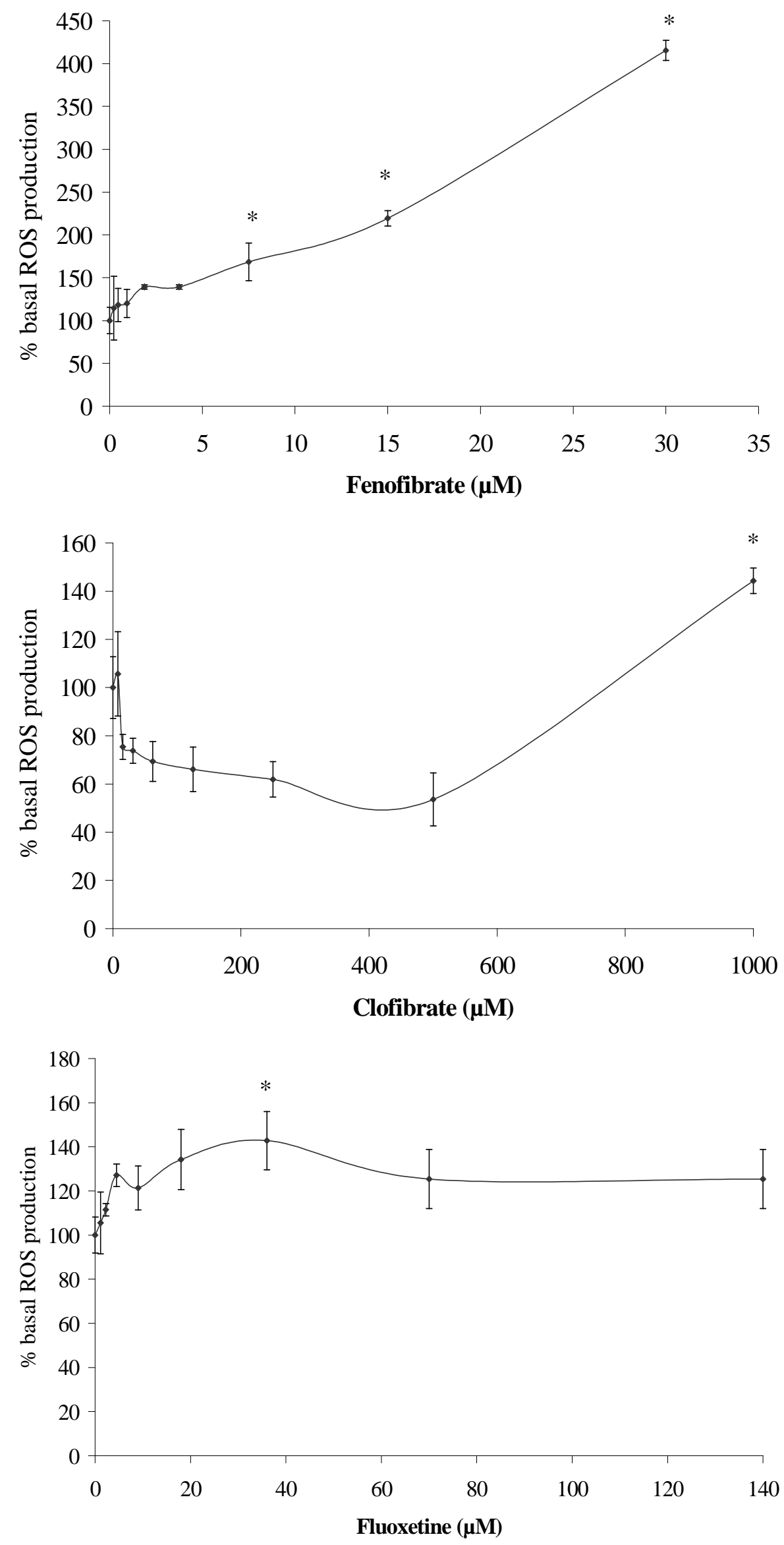

Fig.5. 


\section{$\underline{\text { Tables }}$}

Table 1.

Tested concentrations of pharmaceuticals on primary rainbow trout hepatocytes (PRTH) and PLHC-1 cell line and $\mathrm{EC}_{50}$ of cytotoxicity.

Values are $\mathrm{EC}_{50}$ and confidence interval calculated with MTT results after 24 hours of exposure.

n.m : not modelisable; n.c : not cytotoxic

\begin{tabular}{|c|c|c|c|c|}
\hline \multirow[t]{2}{*}{ Pharmaceutical } & \multicolumn{2}{|c|}{ Tested concentrations $(\mu \mathrm{M})$} & \multicolumn{2}{|c|}{ EC 50 cytotoxicity $(\mu M)$} \\
\hline & & & \multicolumn{2}{|c|}{ Confidence interval with $\alpha=5 \%$} \\
\hline \multirow{3}{*}{ Fenofibrate (FF) } & PLHC-1 & PRTH & PLHC-1 & PRTH \\
\hline & $0.1-15.6$ & $1.9-30$ & 9 & 53 \\
\hline & & & 8- 11 & $28-102$ \\
\hline \multirow[t]{2}{*}{ Clofibrate $(\mathrm{CF})$} & $3.9-500$ & $62.5-1000$ & 2 & 133 \\
\hline & & & $2-3$ & $117-161$ \\
\hline \multirow[t]{2}{*}{ Fluoxetine (FX) } & $1.1-140$ & $9-140$ & 5 & 66 \\
\hline & & & $4-6$ & $44-83$ \\
\hline \multirow{2}{*}{$\begin{array}{l}\text { Propranolol } \\
(\mathrm{POH})\end{array}$} & $3.9-500$ & $31.3-500$ & 85 & 453 \\
\hline & & & $72-102$ & $334-690$ \\
\hline \multirow{2}{*}{$\begin{array}{l}\text { Diclofenac } \\
\text { (DiCF) }\end{array}$} & $3.9-500$ & $31.3-500$ & 19 & 420 \\
\hline & & & $11-29$ & $361-480$ \\
\hline \multirow{2}{*}{$\begin{array}{c}\text { Gadolinium } \\
\text { chloride }\left(\mathrm{GdCl}_{3}\right)\end{array}$} & $7.8-1000$ & $62.5-1000$ & 262 & 963 \\
\hline & & & $112-789$ & $672-1516$ \\
\hline \multirow{2}{*}{$\begin{array}{c}\text { Carbamazepine } \\
\text { (CBZ) }\end{array}$} & 3.9500 & $31.3-500$ & 651 & 318 \\
\hline & & & $344-2127$ & $253-401$ \\
\hline $\begin{array}{c}\text { Sulfamethoxazol } \\
\text { e (SFX) }\end{array}$ & $3.9-500$ & $31.3-500$ & n.m & n.m \\
\hline $\begin{array}{l}\text { Amoxicillin } \\
(\mathrm{AMX})\end{array}$ & $3.9-500$ & $31.3-500$ & n.c & n.c \\
\hline
\end{tabular}


Table 2.

EROD $\mathrm{EC}_{50}$ of 9 pharmaceuticals tested on primary rainbow trout hepatocytes (PRTH).

Values are $\mathrm{EC}_{50}$ with confidence interval calculated with EROD results after 24 hours of exposure.

*Inhibitors of the basal EROD activity at sublethal concentration.

\begin{tabular}{|c|c|c|}
\hline Pharmaceutical & $\begin{array}{c}\text { Effect on the basal EROD } \\
\text { activity }\end{array}$ & $\mathrm{EC}_{50} \mathrm{EROD}$ \\
\hline Fenofibrate $(\mathrm{FF})^{*}$ & Inhibition & $\begin{array}{c}25 \\
13-30\end{array}$ \\
\hline Diclofenac $(\mathrm{DiCF})^{*}$ & Inhibition & $\begin{array}{c}63 \\
62-68\end{array}$ \\
\hline Fluoxetine (FX) & Inhibition & $\begin{array}{c}77 \\
58-95\end{array}$ \\
\hline Clofibrate $\left(\mathrm{CF}^{*}\right.$ & Inhibition & $\begin{array}{c}96 \\
88-104\end{array}$ \\
\hline Sulfamethoxazole (SFX)* & Inhibition & $\begin{array}{c}108 \\
78-144\end{array}$ \\
\hline Carbamazepine $(\mathrm{CBZ})^{*}$ & Inhibition & $\begin{array}{c}318 \\
253-401\end{array}$ \\
\hline $\begin{array}{l}\text { Gadolinium chlorhyde } \\
\qquad\left(\mathrm{GdCl}_{3}\right)\end{array}$ & Inhibition & $\begin{array}{c}371 \\
279-482\end{array}$ \\
\hline Propranolol (POH) & Induction & $\begin{array}{c}27 \\
1-44\end{array}$ \\
\hline Amoxicillin (AMX) & No effect & - \\
\hline
\end{tabular}

